\title{
THERMAL TREATMENT OF ALUMINOUS PHOSPHATES OF THE CRANDALLITE GROUP AND ITS EFFECT ON PHOSPHORUS SOLUBILITY
}

\author{
Eros Artur Bohac Franciscoํ; Luís Ignácio Prochnow²*; Maria Cristina Motta de Toledo³; \\ Viviane Carillo Ferrari³; Sérgio Luís de Jesus ${ }^{4}$ \\ ${ }^{1}$ Faculdades Integradas de Rondonópolis, Av. Presidente Kennedy, 1439 - 78700-300 - Rondonópolis, MT - \\ Brasil. \\ ${ }^{2}$ USP/ESALQ - Depto. de Ciência do Solo, C.P. 9 - 13418-900 - Piracicaba, SP - Brasil. \\ ${ }^{3}$ USP/IG - Depto. de Geologia Sedimentar e Ambiental, R. do Lago, 562 - 05508-080 - São Paulo, SP - Brasil. \\ ${ }^{4}$ USP/ESALQ - NUPEGEL, Núcleo de Pesquisa em Geoquímica e Geofísica da Litosfera \\ *Corresponding author <liprochn@esalq.usp.br>
}

\begin{abstract}
Optimization in the use of phosphate rocks is important and the residues of fertilizer production in the form of crandallite may be suitable for agronomic use after calcination. With the objective of evaluating the effect of thermal treatment of the aluminous phosphates of the crandallite group as related to solubility, crystalline structure and morphology, samples from the mine residues of three Brazilian phosphate deposits (Tapira-MG, Catalão-GO, and Juquiá-SP) were collected, air-dried, and screened to 100 mesh. Sub samples were thermally treated at $300,500,700$, and $900^{\circ} \mathrm{C}$ for 2 hours. Treated and untreated materials were analyzed by X-ray diffraction, scanning electronic microscopy, energy dispersive X-ray spectrometry, and for the total and soluble P contents. The treatment of samples: (i) raised P solubility in neutral ammonium citrate solution, (ii) caused the disorganization of the crystalline structure of crandallite at $500^{\circ} \mathrm{C}$ and above, and (iii) altered their morphology (cracking and rounding). The increase in P solubility of samples after calcination indicates that the agronomic utilization of these marginal P sources may be of interest since plant growth may be favored due to higher P availability. New studies to evaluate these materials in order to determine their agronomic effectiveness must be carried out to establish adequate conditions that favor their use by plants. Key words: calcination, phosphate fertilizer, phosphate impurities
\end{abstract}

\section{TRATAMENTO TÉRMICO DE FOSFATOS ALUMINOSOS DO GRUPO DA CRANDALLITA E SEU EFEITO NA SOLUBILIDADE DO FÓSFORO}

\begin{abstract}
RESUMO: A otimização do uso de rochas fosfáticas é importante e resíduos da indústria de fertilizantes fosfatados na forma de crandallita poderão ser agronomicamente eficientes após calcinação. Com o objetivo de avaliar o efeito do tratamento térmico em fosfatos aluminosos do tipo crandallita quanto à solubilidade, estrutura cristalina, e morfologia, amostras do rejeito de mineração de três depósitos fosfáticos brasileiros (Tapira-MG, Catalão-GO e Juquiá-SP) foram coletadas, secas ao ar e separadas por peneiramento 100 mesh. Sub-amostras foram submetidas ao tratamento térmico a 300, 500, 700 e $900^{\circ} \mathrm{C}$ durante 2 horas. Os materiais tratados e não-tratados foram analisados por difratometria de raios X, observados por microscopia eletrônica de varredura e espectrometria por energia dispersiva, e seus teores de fósforo total e solúvel determinados. O tratamento térmico das amostras: (i) elevou, consideravelmente, a solubilidade em CNA dos materiais; (ii) promoveu a desorganização da estrutura cristalina da crandallita a temperaturas de $500^{\circ} \mathrm{C}$ e superiores; e (iii) causou alterações morfológicas (fraturamento e arredondamento) nas amostras. O aumento na solubilidade das amostras após o tratamento térmico indica que a utilização agronômica destas fontes marginais de P pode ser de interesse, uma vez que o crescimento das plantas pode ser favorecido pela maior disponibilidade de P. Estudos de avaliação desses materiais a fim de determinar sua eficiência agronômica devem ser conduzidos para o conhecimento de condições adequadas para sua aplicação que favoreçam o aproveitamento pela planta. Palavras-chave: calcinação, fertilizante fosfatado, impurezas em fertilizantes fosfatados
\end{abstract}

\section{INTRODUCTION}

Soil phosphorus availability has been one of the most limiting factors for crop production. Tradi- tionally the application of P sources of high water solubility, i.e., superphosphates and ammonium phosphates, has supported high yields. However, the manufacturing process of high water-soluble $\mathrm{P}$ sources 
(WSP) requires the use of high quality apatitic phosphate rocks, containing low quantities of metal impurities such as iron and aluminum (Hoare, 1980). This requirement has forced the industry to produce high amounts of residues, not suitable in the acidulation process of WSP fertilizers.

Weathering of apatite causes $\mathrm{P}$ dissolution and release of orthophosphate ions that bind with cations in solution forming secondary minerals such as the aluminous phosphates from the crandallite group (Toledo, 1999). The following chemical formulas were proposed: $R \mathrm{Al}_{3}\left(\mathrm{PO}_{4}\right)\left(\mathrm{PO}_{3} \mathrm{OH}\right)\left(\mathrm{OH}_{6}\right)$, when $R$ is calcium (crandallite) or barium (gorceixite), $R \mathrm{Al}_{3}\left(\mathrm{PO}_{4}\right)_{2}\left(\mathrm{OH}_{6}\right)$, when $R$ are rare earth elements, or $R \mathrm{Al}_{3}\left(\mathrm{PO}_{4}\right)_{2}\left(\mathrm{OH}_{5}\right) \cdot \mathrm{H}_{2} \mathrm{O}$, when $R$ is lead (plumbogummite) (Blackburn \& Dennen, 1997).

In Brazil, crandallite minerals are present in phosphate deposits of the Southeast region (Toledo, 2000), and also in the North and Northeast regions (Guardani, 1987). These aluminous phosphates are unsuitable to be used in the acidulation process, but were once marketed worldwide as $\mathrm{P}$ sources for direct application after their thermal treatment (Doak et al., 1965; Mason \& Cox, 1969).

Despite their poor water solubility, these minerals normally present high solubility in neutral ammonium citrate (NAC) after calcination due to the collapse of the crystalline structure (Buchan et al., 1970; Gilkes \& Palmer, 1979). In Brazil some studies showed increase in P solubility and reasonable agronomic results after calcination (Câmara et al., 1984; Guardani, 1987). The objective of this work was to evaluate the effect of the thermal treatment (calcination) of aluminous phosphates of the crandallite group from three Brazilian phosphate deposits on: (i) P solubility, (ii) alterations of crystalline structure, and (iii) morphology.

\section{MATERIAL AND METHODS}

Representative samples from the phosphate

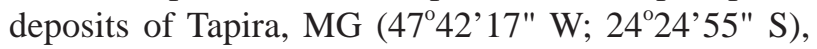

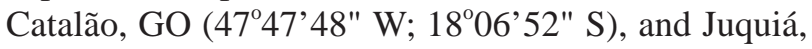
SP (464' 40" W; 195' $17^{\circ}$ " S), were evaluated. Phosphate mines were chosen because of their importance for the Brazilian fertilizer manufacturing industry. In these locations, the crandallite group is part of the weathering lateritic mantle, constituted by the upper weathered layer that covers the apatitic material. The mining process removes this weathered material that is classified as a reject.

Bulk samples were collected at the mining reject pile and air-dried. The dried bulk samples were screened to 100 mesh $(150 \mu \mathrm{m})$ and submitted to ther- mal treatment in a muffle furnace at 300, 500, 700, and $900^{\circ} \mathrm{C}$ for 2 hours, without addition of any reagent, followed by cooling at room temperature around $23^{\circ} \mathrm{C}$. Treated and untreated sub samples were then analyzed by X-ray diffraction (XRD) in order to determine the mineral phases using a Philips $\mathrm{X}$-ray powder diffractometer, from 3 to $90^{\circ} 2 \theta \mathrm{min}^{-1}$ with a step size of $1.2^{\circ} 2 \theta \mathrm{min}^{-1}$, with $\mathrm{Cu}$ radiation produced at a power setting of $40 \mathrm{kV}$ and $40 \mathrm{~mA}$. X-ray diffraction data were analyzed using the PC-APD/ PHILIPS software and JCPDS (1980) database. Treated and untreated sub samples were also chemically analyzed in order to determine total and neutral ammonium citrate (NAC) soluble P contents, according to the official methods of fertilizer analysis (Embrapa, 1999). Finally, treated and untreated sub samples were scanned in a Jeol 5600 LV Scanning Eletronic Microscope (SEM) with accelerating voltage of $20 \mathrm{kV}$, using also an Energy Dispersive Spectroscopy (EDS)/NORAM equipment. This scanning procedure consisted of looking for structure alterations, i.e., agglutination, porosity, morphology, compaction, and distribution, with qualitative and semiquantitative identification of elements.

\section{RESULTS AND DISCUSSION}

Total and NAC soluble $\mathrm{P}$ analysis showed a small increase in total $\mathrm{P}$ content upon heating, due to loss of hydration water, as well as a large increase in NAC solubility (Table 1). Tapira, Catalão, and Juquiá presented higher solubility in NAC upon treatment (Figure 1): (i) for Tapira, NAC solubility reached $84 \%$ at $700^{\circ} \mathrm{C}$; (ii) for Juquiá, the maximum solubility was $60 \%$ around $500^{\circ} \mathrm{C}$; and (iii) Catalão presented the lowest NAC solubility of all, reaching only $44 \%$ at 700 ${ }^{\circ} \mathrm{C}$. Similar increases in solubility were reported by

Table 1 - Chemical properties of calcined and untreated samples from Tapira-MG, Catalão-GO, and Juquiá-SP.

\begin{tabular}{lccc}
\hline Analysis & Tapira & Catalão & Juquiá \\
\hline Untreated sample & & $\mathrm{g} \mathrm{kg}^{-1}$ & \\
Total P & 12 & 24 & 79 \\
NAC ${ }^{1}$ Soluble P & $<1$ & $<1$ & 4.6 \\
Water Soluble P & 0 & 0 & 0 \\
Treated sample & & & \\
Total P & 16 & 25 & 90 \\
NAC Soluble P & 8.7 & 4 & 48 \\
Water Soluble P & $<1$ & $<1$ & $<1$ \\
\hline
\end{tabular}

${ }^{1} \mathrm{NAC}$, neutral ammonium citrate extraction. 
Gilkes \& Palmer (1979). All materials had a reduction in solubility with temperatures above $700^{\circ} \mathrm{C}$, which may be associated with an increase in crystalinity of amorphous residues (Guardani, 1987; Gilkes \& Palmer, 1979).

X-ray powder diffraction patterns obtained for untreated samples are presented in figure 2. Crandallite (group), goethite, and kaolinite were identified in all untreated samples. Additionally, quartz and anatase were identified in Catalão, and anatase in Tapira. Slight variations were observed in the diffraction pattern peak positions relative to published (ICDD/JCPDS card file, 19-535) data for crandallite (calcium). The general chemical composition of the crandallite group from Tapira, Catalão, and Juquiá are as follows: (i) gorceixite ( $R$, barium) is the dominant member encountered in Catalão and

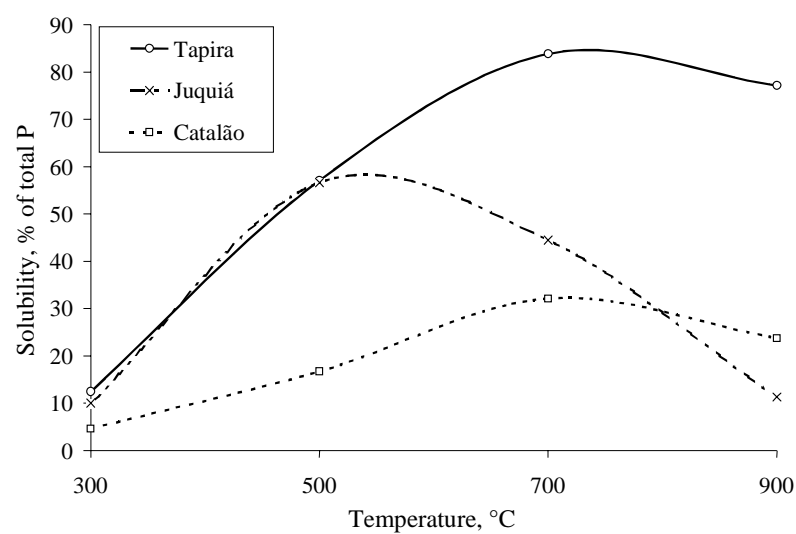

Figure 1 - Thermal treatment effect on phosphorus solubility in neutral ammonium citrate solution.

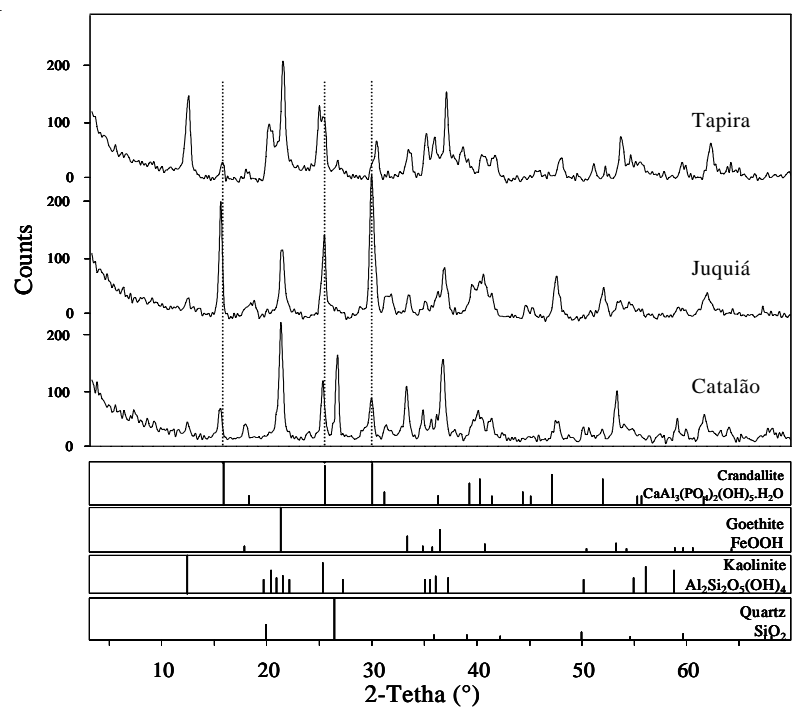

Figure 2 - X-ray diffractograms for Tapira, Catalão, and Juquiá residues and powder diffraction file data for the minerals crandallite, goethite, kaolinite and quartz.
Juquiá; (ii) goyazite ( $R$, strontium) and gorceixite are the predominant members in Tapira; and (iii) Fe substitutes $\mathrm{Al}$ in crandallite structure in various proportions in those materials (Toledo et al., 2002). These characteristics may affect unit cell dimensions, as observed by Botinelly (1976), for some phosphates of the alunite-jarosite type, and explains the discrepancies in X-ray diffraction peak positions (Figure 2).

These aluminous phosphates are the result of new formations during cycles of disorganization and reprecipitation of phosphates in lateritic zones on igneous rocks of alkaline-carbonatitic complexes (Toledo, 1999), like those here studied. Total P content of these materials is very low due to the chemical characteristics of the rocks and the phosphorus release during the weathering process, and hence the formation of secondary phosphates. For instance, all samples from Catalão and Tapira showed in average $20 \mathrm{~g} \mathrm{~kg}^{-1}$ of total $\mathrm{P}$, since the main objective was to select samples with aluminous phosphates of the crandallite group exclusively.

Figure 3 shows the effect of thermal treatment on mineral composition of Juquiá from 300 to $900^{\circ} \mathrm{C}$, with no crandallite identified at higher temperatures and a strong broad diffraction band centered at 15 and $30^{\circ} 2 \theta$ (result observed for all treated samples). Thermal treatment caused transformation of goethite into hematite $\left(\alpha-\mathrm{Fe}_{2} \mathrm{O}_{3}\right)$. When the crandallite structure is heated to $700^{\circ} \mathrm{C}$ and above, new crystalline structures can develop, i.e., whitlockite or phosphocristobalite (Gilkes \& Palmer, 1979), which were not observed in

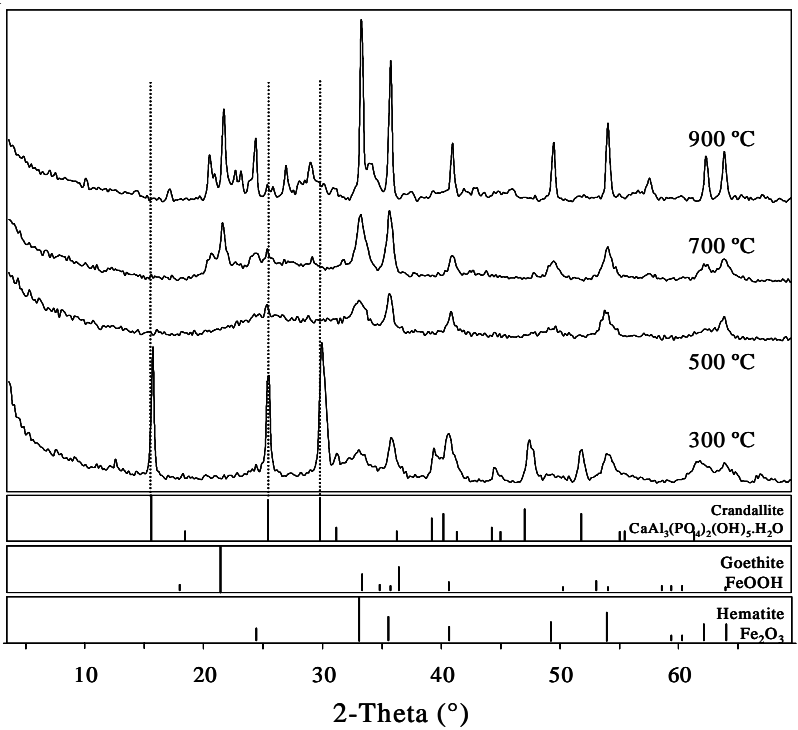

Figure 3 - X-ray diffractograms for Juquiá residue calcined at 300, 500, 700, and $900^{\circ} \mathrm{C}$ and powder diffraction file data for the minerals crandallite, goethite and hematite. 
the present study. In accordance with Doak et al. (1965), Câmara et al. (1984), Guardani (1987), it is possible to suggest that the structural disorganization upon thermal treatment may occur in response to the loss of hydration water, which could provoke collapse of the crystalline structure. The same effect of calcination on mineralogical composition was observed for Tapira and Catalão, that is, original goethite was gradually transformed into hematite following heating, and the crystalline structure of aluminous phosphates of the crandallite group was disorganized at $500^{\circ} \mathrm{C}$ and higher temperatures. However, the loss of crystalline structure of crandallite in Catalão was not complete enough to cause the disappearance of X-ray diffraction peaks, as occurred for Juquiá and Tapira (Figure 4). The time of heating exposition of samples (2 hours) used in this study might not have been sufficient to promote a complete crystalline structure disorganization of crandallite present in Catalão, or that the sample heating was not homogeneous. This could explain the difference in solubility among the samples shown in Figure 1, where heated Catalão showed the lowest NAC solubility.

Morphology and EDS analyses of untreated samples (Figure 5) show that for Juquiá and Tapira, aluminous phosphates of the crandallite group are seen as rhombic or tetrahedral crystals. In the first case, it is possible to analyze for EDS portions of the sample containing phosphate because there are well-

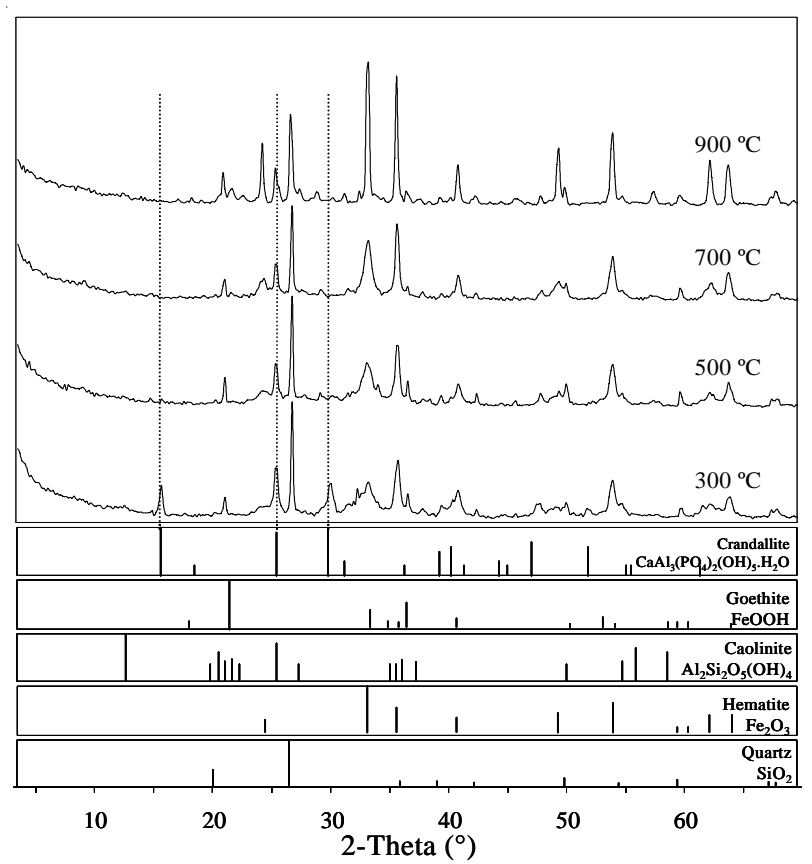

Figure 4 - X-ray diffractograms for Catalão residue calcined at $300,500,700$, and $900^{\circ} \mathrm{C}$ and powder diffraction file data for the minerals crandallite, goethite, kaolinite, hematite and quartz. developed crystals. For Juquiá, the EDS spectrum indicates that crystals are closely associated with ferruginous material. For Catalão, crandallite is seen associated with upper layer minerals (silicates) and not only carbonate minerals, such as in Juquiá (Toledo, 2000).

Thermal treatment promoted structural alterations on samples causing the cracking of regions that were earlier continuous, which could have caused an increase in specific surface of the sample and further increase of phosphorus solubility (Figure 6 (A)). Figure 6 (B) shows the effect of thermal treatment $\left(500^{\circ} \mathrm{C}\right)$ on Juquiá samples causing alteration of shape (rounding), especially at regions rich in Fe (hematite) due to fusion of materials. This effect may have led to solubility decreases due to trapping of crandallite.

The process of calcination appears to be a suitable option for crandallite minerals, once the acidulation process, used for apatitic phosphate rocks, presents the inconvenience of metal impurities solubilization. Another alternative presented in the literature to process these materials is the treatment with alkaline reagents following precipitation and aluminum separation (Braun, 1983), however, an insoluble phosphate residue resulted from Christmas Island C-grade material treated with sodium hydroxide showed unsatisfactory results for grassland production (Longhurst \& O’Connor, 1988).

The utilization of industrial reactors for thermal treatment of materials containing aluminous phosphates of the crandallite group is operationally viable once calcination tests were already carried out, as reported by Guardani et al. (1989). Their results indicated that circulating fluidized bed type reactors are the most efficient for decomposition of these materials.

In recent years, little scientific information has been published about the industrial production of phosphate fertilizers derived from aluminous phosphates. Our results identify transformations upon heating and an increase in P solubility for the tested materials, with consequent potential agronomic use of these minerals in the future. New studies are necessary on the agronomic and economic suitability of the process. A beneficiation process should also be necessary to concentrate the final fertilizers in $\mathrm{P}$.

\section{ACKNOWLEDGMENTS}

To FAPESP for the scholarship that made this work possible, and to Socal S/A Mineração and Fertilizantes Fosfatados S/A - FOSFERTIL, for providing the samples. 

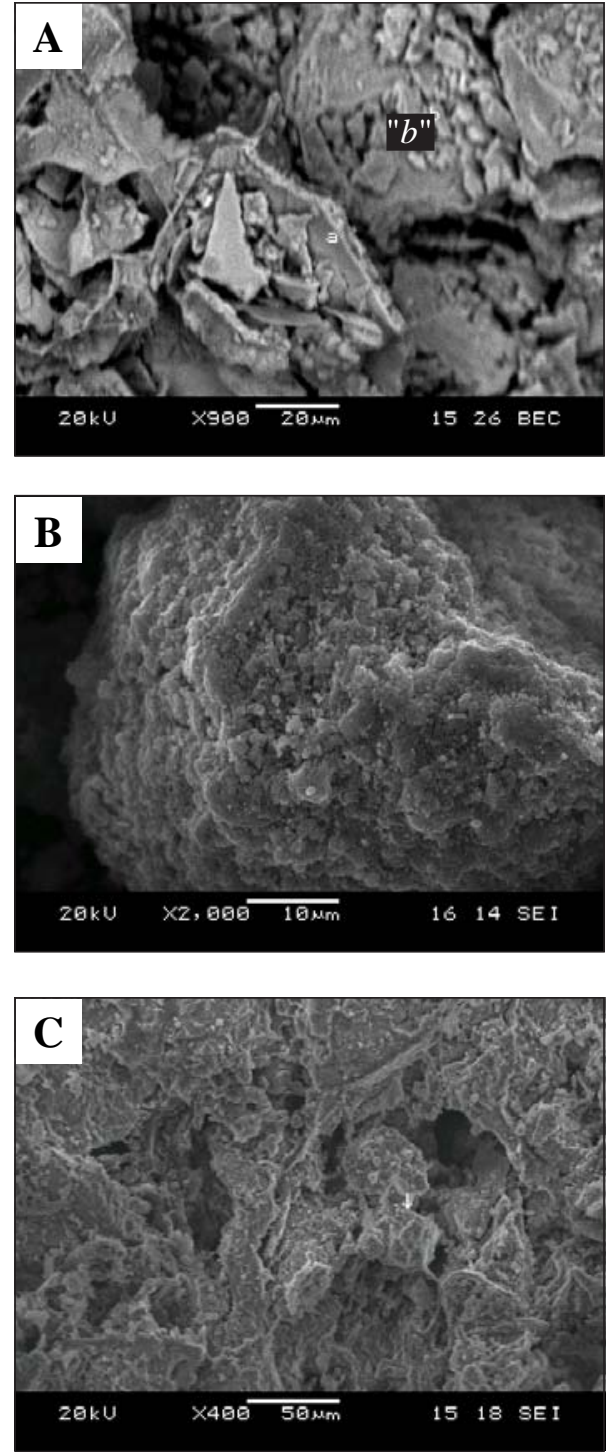
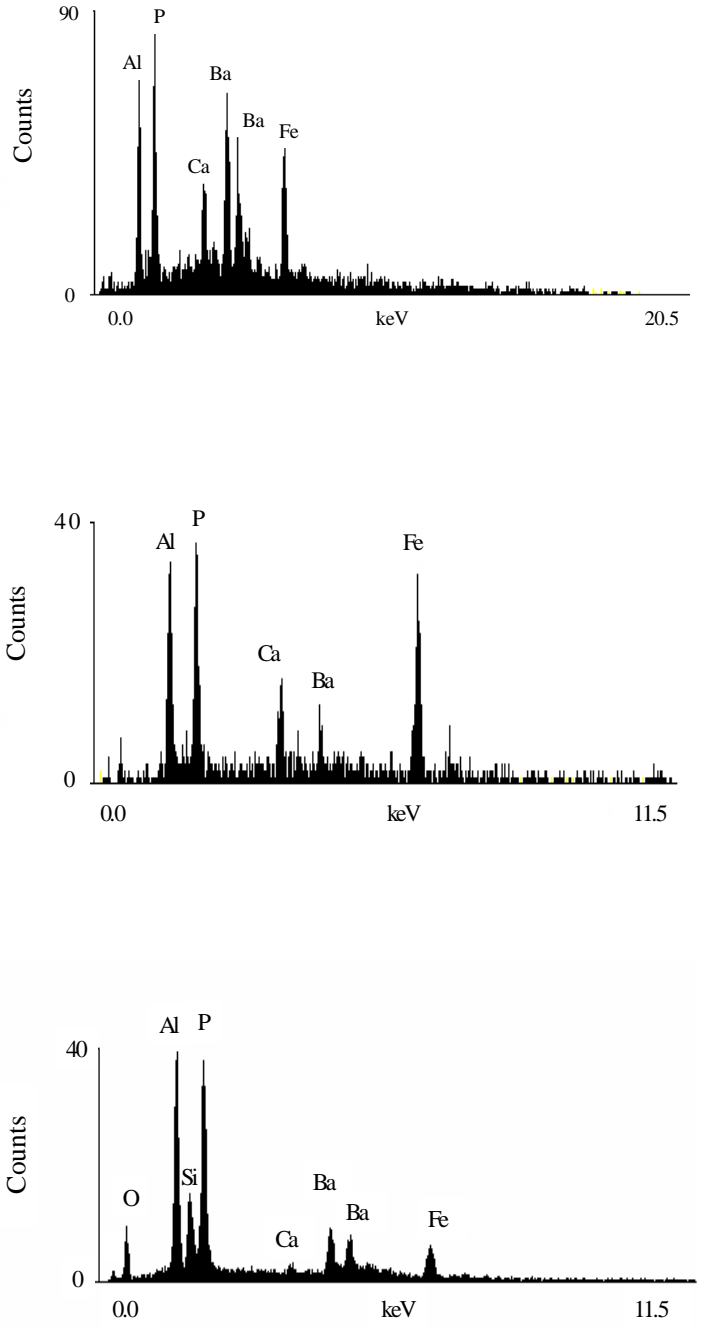

Figure 5 - Aluminous phosphates of the crandallite group: (A) Tapira, cracking material in alteration plasma constituted by rhombic and tetrahedral crystals and EDS graph analysis of area " $b$ " to the right; (B) Juquiá, angular crystals covering ferruginous phase and general EDS graph analysis to the right; (C) Catalão, porous material recovering crandallite crystal in silicateferruginous phase and punctual EDS graph analysis of indicated region to the right.
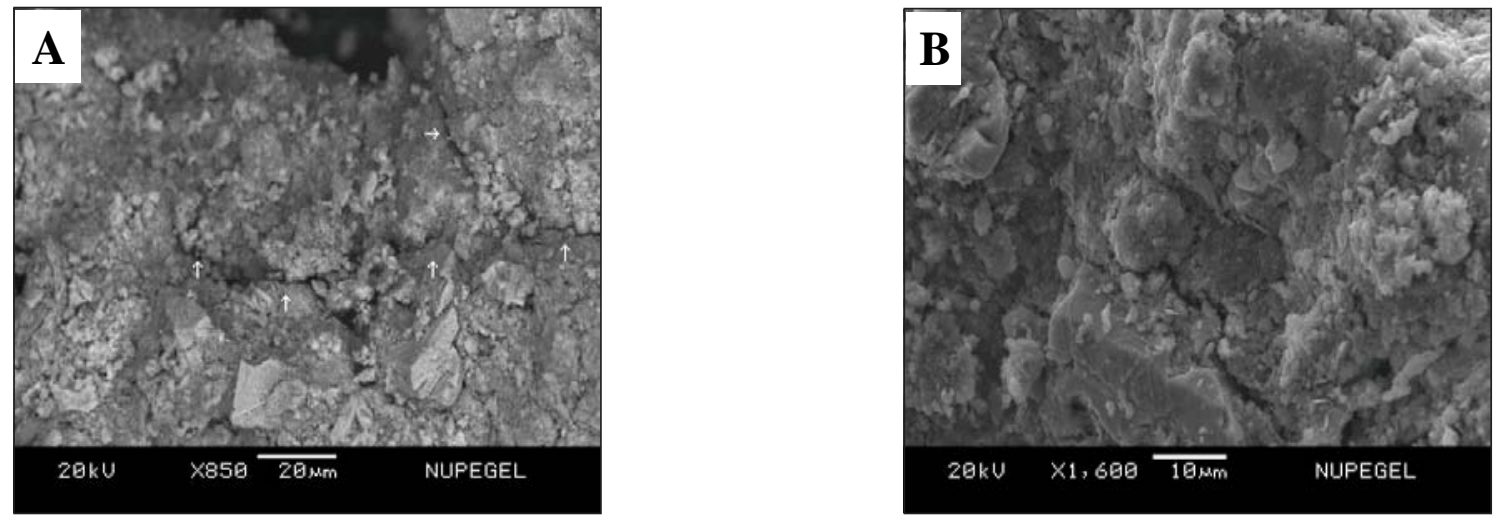

Figure 6 - Aluminous phosphates of the crandallite group from Juquiá-SP: (A) structural alteration (cracking) caused by thermal treatment $\left(500^{\circ} \mathrm{C}\right)$; (B) morphological condition (rounding) altered by thermal treatment of sample $\left(500^{\circ} \mathrm{C}\right)$. 


\section{REFERENCES}

BLACKBURN, W.H.; DENNEN, W.H. Encyclopedia of mineral names. Ottawa: Mineralogical Association of Canada, 1997. 360p.

BOTINELLY, T. A review of the minerals of the alunite-jarosite, beudantite, and plumbogummite groups. Journal of Research of the United States Geological Survey, v.4, p.213-216, 1976.

BRAUN, W.A.G. Os fosfatos de alumínio do Brasil, sua tecnologia e uso agrícola. Fertilizantes, v.5, p.3-11, 1983.

BUCHAN, J.A.J.; MULLER, F.B.; ROGERS, J.; SEAGER, R.H.; YONG, T.A. Agronomic use of calcined Christmas Island iron/ aluminium phosphates. II. Pot trials. New Zealand Journal of Agricultural Research, v.13, p.465-480, 1970.

CÂMARA, L.M.J.R.; RIBEIRO, J.F.; FERNANDES, M.S. Efeito da temperatura de calcinação na eficiência de fosfatos de alumínio como fertilizante. Revista Brasileira de Ciência do Solo, v.8, p.345-347, 1984.

DOAK, B.W.; GALLAHER, P.J.; EVANS, L.; MULLER, F.B. Low temperature calcination of "C"-grade phosphate from Christmas Island. New Zealand Journal of Agricultural Research, v.8, p.1529, 1965.

EMPRESA BRASILEIRA DE PESQUISA AGROPECUÁRIA. Manual de análises químicas de solos, plantas e fertilizantes. Rio de Janeiro: Embrapa Solos, 1999. 372p.

GILKES, R.J.; PALMER, B. Calcined Christmas Island C-grade rock phosphate fertilizers: mineralogical properties, reversion and assessment by chemical extraction. Australian Journal of Soil Research, v.17, p.467-481, 1979.

GUARDANI, R. Transformações térmicas e solubilidade de fosfatos de alumínio dos estados do Pará e Maranhão. Fertilizantes, v.9, p.6-10, 1987.
GUARDANI, R.; DRAHOS, J.; GIULIETTI, M.; SCHUGERL, K. Studies on calcinations of aluminium phosphate rock in fluidized bed reactors. Fertilizer Research, v.20, p.181-191, 1989.

HOARE, J. Phosphate raw materials and fertilizers: Part II - A case history of marginal raw materials. In: KHASAWNEH, F.E.; SAMPLE, E.C.; KAMPRATH, E.J. The role of phosphorus in agriculture. Madison: ASA, 1980. chap.1, p.121-128.

INTERNATIONAL CENTRE FOR DIFRACTION DATA - JCPDS. Powder diffraction file: search manual - Hanawalt method inorganic. Pennsylvania, 1980. 896p.

LONGHURST, R.D.; O'CONNOR, M.B. Field evaluation of pelletised calcined and insoluble residue of Christmas Island ' $C$ ' phosphates. New Zealand Journal of Experimental Agriculture, v.16, p.179181, 1988.

MASON, M.G.; COX, W.J. Calcined rock phosphate as fertilizer for pasture and cereal production in Western Australia. Australian Journal of Experimental Agriculture and Animal Husbandry, v.9, p.99-104, 1969.

TOLEDO, M.C.M. Os fosfatos aluminosos da série da crandallita uma revisão. Revista do Instituto Geológico, v.20, p.49-63, 1999.

TOLEDO, M.C.M. O grupo da crandallita no manto laterítico sobre o maciço carbonatítico de Catalão I, GO - Brasil. Geochimica Brasiliensis, v.14, p.71-95, 2000.

TOLEDO, M.C.M.; FERRARI, V.C.; ALCOVER NETO, A.; FONTAN, F.; MARTIN, F.; SANTOS, C.N.; CARVALHO, F.M.S. Fosfatos aluminosos com ferro do grupo da crandallita nas coberturas lateríticas de Catalão I, Juquiá e Tapira, Brasil, e Chiriguelo, Paraguai. Revista Brasileira de Geociências, v.32, p.389-402, 2002.

Received May 31, 2006

Accepted March 23, 2007 